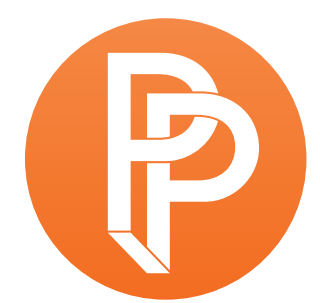

PERFORMANCE

PHILOSOPHY

\title{
“OUT, AND UNDER, AND OUT, AND OUT." SELF-(DIS-)ORGANISATION AND THE STORIES OF LIBERTATIA
}

\section{GEORGDOCKER UNIVERSITY OF ROEHAMPTON}

\section{Self-Organisation in Performance. An Extensive Introduction}

In the middle of the many social and political struggles, which have come to define large parts of the early- $21^{\text {st }}$ century stream of events, experimental performing arts in Europe too have been undergoing quite remarkable changes of their socio-political compositions. Subsidy cuts, the attempted closings and privatisations of theatre venues, the institutions' further expansion of their control-oriented operative models of co-production and curation, or the ongoing degradation of women, people of colour, and other non-male, non-white identifying subjects in rehearsals and on stage-these and further trends in European theatre, dance, and performance have not gone unnoticed, to say the least. Quite on the contrary, practitioners have met the multiple challenges with the active engagement in a wide range of projects aiming for the creation of distinct sociopolitical alternatives, no matter how much of a preliminary or partial solution they might pose. A necessarily incomplete list of initiatives would have to include at least some of the following names and spaces:

There is PAF, for example, the Performing Arts Forum in St. Erme, Northern France, which was founded by Jan Ritsema and colleagues in 2005 and has since been upheld by a wide number of temporary inhabitants who all together continuously engage in non-institutionally framed, 
autonomous, and inclusive production and discourse; similar residency spaces for collective working include Massia, PAF's offspring in Massiaru, Estonia, and the Bidston Observatory in the United Kingdom. A more aggressive tactics of direct intervention has been the motor for theatre occupations all over Europe, two of them being the 2011 occupation of Embros Theatre in Athens, which, despite phases of severe internal conflict, can look back at years of sustained social and artistic practice, and the group VB 61-12's occupation of Volksbühne in 2017, which, although shortlived, sparked public debate around the political agency of a theatre in a rapidly changing city like Berlin and fostered continuing exchange in social media forums. Still other initiatives have been providing tools for the establishing of social infrastructures necessary for mutual exchange in the artistic communities, as there are, for example, the online and physical sharing platforms Everybody's Toolbox and Nobody's Business, which organised and keep organising artist meetings in various studios and theatre places from different countries, keeping detailed records of their activities on their websites so as to make results available for everyone.

Staying with examples like these, it is interesting to observe that the majority of them has in common not only a decisively radical political positioning, but also, and more specifically, the strong affirmation of the practice and concept of self-organisation. Their engagement in selforganising principles varies according to the specific aims and needs of each situation: it might take on the form of weekly general assemblies as in the case of Embros, it might consist in the collective programming and realisation of a daily schedule as in the Volksbühne occupation, or it might involve the commitment to the three rules "don't leave traces," "make it possible for others," and "the do-er decides" as in PAF (cf. Ritsema/Desideri 2016). It might also come with different languages and vocabularies, ranging from the use of contemporary keywords such as "opensource" and "sharing" (cf. Nobody's Business, n.d.), to framing programmes as "self-initiated" and "ad-hoc" (cf. Bidston Observatory 2018), to explicitly referencing the notion of self-organisation on the occasions of lectures and essays (cf. Ritsema 2017; Argyropoulou 2017). The unifying momentum of all these options, however, is that they are being pursued with the intention of bringing forth a space and culture of equal and equally freeing relations, which is to say that at the heart of these projects is the commitment to self-organisation as a commitment to social and artistic liberation. And most importantly perhaps, in several cases, existing ideas of selforganisation are less applied than experimented with, Everybody's inventions of scores and tasks for different modes and relations of exchange serving as just one example of the generally nonorthodox approach to self-organisation.

The engagement in and experimentation with self-organisation can thus be said to be among the most generative of socio-political activities in the experimental European performing arts scenes these days. Assuming that this diagnosis about the importance of self-organisation is correct, there is the potential for many subsequent enquiries. Relevant questions might address the historical lineage of self-organisation in performing arts-the neo avant-gardes, Living Theatre, or the Frankfurter "Mitbestimmungsmodell" ranging among the possible references-or the contextual similarities and differences between self-organisation in performing arts and self-organisation simultaneously being practiced in the non-artistic realm of political action-the so called antiglobalisation movement and Occupy Wall Street as the most obvious references in this latter case 
(cf. for example Graeber 2002). For the purpose of this paper, I decided to choose a different option, though, namely to invest less in a contextualisation or analysis of performing arts selforganisation, and more in a theoretical response. This response-led methodology is stimulated by several concerns, the most important one perhaps being that any conventional analysis as a writing about, however valuable it might be, risks to execute, if only on the level of language, precisely what self-organisation most often tries to escape, namely an act of subjection or objectification. The format of the theoretical response, instead, is more of a writing in relation to and a writing for, a writing, which tries to contribute to the raised issue by adding to it in its very own conceptual terms, aiming to produce knowledge that might eventually benefit those who the writing originally responded to. In other words, I will not, over the next couple of pages, dissect or come back to any of the just mentioned experiments from the performing arts, but I will develop a discussion of the concept, or rather the concepts of self-organisation relevant for them and their further unfolding, and I will do so not least by adapting a likewise somewhat experimental approach.

More concretely, I will deploy a particular fictional narrative with a history of almost three hundred years in order to intertwine with and through it three existing concepts of self-organisation. The narrative in question is the pirate-utopia Libertatia, and the concepts in question are anarchist, cybernetic, and vitalist-materialist self-organisation. The choice of these specific concepts is motivated by mainly three factors: first, they are historically and theoretically among the most dominant concepts in the more general discourse on self-organisation, although many other, often related accounts from biology, feminist theory, the black radical and further radically leftist traditions have equally proven to be insightful (for recent examples cf. Haraway 2016; Lorey 2015, chapter "Care Crisis and Care Strike"; Moten/Harney 2013; Berardi 2017); second, they are to some extent historically interconnected-research on anarchism, for example, having shown that the surfacing of the precise notion of self-organisation in anarchist discourse is most probably owed to the publication of a cybernetic paper in an anarchist journal from the $1960 \mathrm{~s}$, which led to a change in the very anarchist understandings of social developments (cf. Schaupp 2017; Duda 2013; McEwan 1963); third, all of them are in some ways present in the performing arts discourse, with Jan Ritsema (cf. 2017), for example, having mentioned anarchist self-organisation and anarchist writer Hakim Bey's related concept of the temporary autonomous zone (cf. 1991) among his influences, and Gigi Argyropoulou from Embros (cf. 2017, 2018) having often quoted from Tiqqun, or the Invisible Committee, as they called themselves later on, a collective that is closely aligned with anarchist discourse and which is well known not least for its fierce criticism of cybernetics (cf. Tiqqun 2001; Invisible Committee 2015).

I should add that my choice of references from within anarchism, cybernetics, and vitalist materialism is certainly selective: in the case of anarchism, I will focus on the social libertarian heritage (for an overview see cf. Chomsky 1970), and particularly on Mikhail Bakunin and Emma Goldman, whereas I will ignore, for example, individualist approaches emanating from Max Stirner (cf. [1844] 1995), which have regained importance in some of the recent post-anarchist debates (cf. Newman 2016; for post-anarchism and its critique cf. Süreyyya/Rousselle 2011; Cohn 2002; Cohn/Wilbur 2003). For cybernetics, I will mainly refer to second generation authors William Ross Ashby and Heinz von Foerster, and for vitalist materialism, I will quote from Félix Guattari. The 
choice of the narrative of Libertatia, in turn, is motivated by the fact that its several reiterations over the course of the centuries-involved authors including Charles Johnson, Don Carlos Seitz, William S. Burroughs, and the Cybernetic Culture Research Unit-have made it somewhat of a palimpsest which encompasses all three concepts of self-organisation, and namely in a way that allows me to perform the intended twists in interpretation or the slightly heretical reading that I aim for.

The hypothesis that I wish to develop is that in all three forms of anarchist, cybernetic, and vitalistmaterialist self-organisation can be found very subtle or sometimes rather obvious clues suggesting that self-organisation is not just incidentally, but necessarily being accompanied by its very opposite of self-dis-organisation. In other words, the story of Libertatia can help display that self-organisation necessarily brings about its very own subversion, and precisely this surplus aspect can be understood not as a weakness, but as the defining quality of self-organisation enabling change, change that is always, first of all, self-change, as one might say, and change, that, in this function, serves as the very prerequisite for social liberation. This specific accentuation of the concept of self-organisation ideally indicates the essential value of the discussion of selforganising principles for performing arts practice in the present and, probably, the years to come.

\section{The Stories of Libertatia. A Combined Narrative}

"One world-one love:-LIBERTATIA"—so goes the refrain to the eponymous single "Libertatia" released by Berlin based indie band Ja, Panik in 2014, a post-ironic and playfully naïve prayer of hope for a different future, which represents probably the most recent of references to Libertatia from pop-cultural and literary discourse; and while it is probably nothing but a happy coincidence that the band's name Ja, Panik evokes the very motif of panic that resides deep within the tale of Libertatia (an aspect that I will discuss in my conclusion), it is definitely not a coincidence that Libertatia, in Ja, Panik's song, finds itself to be the subject of yet another retelling of its story. After all, the very first formulation of Libertatia was in itself already a reiteration: in the late 1720s namely, when Charles Johnson (cf. 1728) delivered the original account of Libertatia in the second volume of his "History of the Pyrates," he expressively did so on the basis of another alleged document, namely a manuscript from so called French Captain Misson, or Mission, as the English translation has it, who is at the same time the protagonist of the story. It has long been debated whether, since the "History of the Pyrates" is an otherwise historical account of actual $17^{\text {th }}$-century pirate events, the reports of Mission could equally be regarded as true, but recent research strongly suggests that Libertatia never existed (cf. Little 2016), thus making the narrative a fiction with nevertheless surprisingly apt historical and geographical coordinates, locating Libertatia on the island of Madagascar in the time around the late- $17^{\text {th }}$, early- $18^{\text {th }}$ century.

Despite being situated in this early modern period, which predated the actual development of anarchist, cybernetic, or vitalist-materialist self-organising principles, already Johnson's contribution contains various plot twists and key words that set the scene for the discussion of at least a proto-anarchist self-organisation. In the early $20^{\text {th }}$ century then, Don Carlos Seitz (cf. [1925] 2012), upon rediscovering the "History of the Pyrates," drafted what is essentially a short summary 
of Johnson's account on Libertatia, however not without making some minor adjustments, which led to a significant deepening of the anarchist traits of the story. Precisely some of these alterations later reappeared in William S. Burroughs' substantial adaptions of Libertatia in two of his novels and a short story, all of which were published in the period between the early 1980s to the early 1990s (cf. 1991, 1987, 1981). More importantly, however, Burroughs added entirely new characters and plot lines to the existing narrative, thus introducing not only vitalist-materialist ideas of selforganisation to Libertatia, but allowing also for speculation about cybernetic self-organisation in its various forms. The latter was further unfolded by the CCRU or Cybernetic Culture Research Unit in a text from the turn of the century (cf. 2017), in which they referenced still another source going by the name of William Kane, a mysterious character, who maintained that, due to the circular effects of a cybernetic folding in time, Burroughs' writing on Libertatia had landed in the hands of no one other than Mission himself, the main character of the story thus having found himself in the odd situation of reading about his actions before they had even occurred. Additionally, the CCRU reevaluated the literary status of the narrative by holding that Libertatia should be regarded not as a mere fiction, but as a report that was just as real as anything else; after all, from the hyperstitional standpoint that the CCRU persistently applied, reality itself was nothing but the condensed product of fictional events, and in that sense fiction and reality were to be regarded as internally related (for the concept of hyperstition in the CCRU cf. Ibid, 35-36).

The combined narrative resulting from these many intertwined story tellings can be conceived of as an intricate general matrix for the discussion of self-organisation. In its most apparent form, it brings about two intertwined set of relations and events, the first of which could be entitled "the Sea as a Life," a quote taken from Johnson's original characterisation $(1728,2)$. In a scenario set around 1700, the high time of sovereign power, colonialism, and early capitalism, young Mission hired on the Victoire, a French man-o-war, which, in one of his first trips aboard, took Mission to Italy, where he got to know the young priest Caraccioli. The priest discovered a friend in Mission and, having been sickened from the hypocrisy of clerical power, immediately decided to join him on ship to go across the Atlantic to the Caribbean. The Victoire headed there to accompany a French merchant ship, which was commanded to travel to the island of Martinique, a transport mission like so many others from that time intended to ship goods, arms, and slaves around the globe.

After having securely escorted the trading vessel to its destination, Mission, Caraccioli, and the rest of the crew found themselves in an engagement with an English battleship, which left all of the Victoire's captains and lieutenants killed, an unforeseeable situation, which the remaining men quickly decided to use to their advantage by denouncing all ties to their French motherland and declaring their ship an independent "Republic of the Sea" (Seitz [1925] 2012, 20). Themselves, they gave the names of "liberty lovers" (Ibid.), declaring that, from now on, they were entirely devoted to a "Life of Liberty" (Johnson 1728, 13). In the following, Mission was declared the new captain, although his position came with no individual ruling power, but only with the task of executing the common decisions that the crew had collectively made via debates and direct votes. The rules that the new community imposed on itself determined that private possessions and all prizes from conquests were to be turned into common property, that hostile vessels were to be fought only 
for self-defence or with the aim of winning just as much as was necessary for self-preservation, and that slaves from other vessels were to be freed and welcomed onto their ship without discrimination of either nationality or race. This, essentially, is what the first constellation of relations and events in the tale of Libertatia is comprised of, most of which is narrated by Johnson and Seitz: European imperialism including state and clerical sovereignty, movements on sea, the sudden absence of power, and a self-determining community with international and anti-capitalist scope.

A second, more extensive scenery, which is largely introduced by Burroughs and the CCRU, comes into view once the sailors, after a long cruise from the Caribbean across the South Atlantic and down the western coast of Africa to the other side of the continent, voted to leave the life on the sea behind and settle down on the island of Madagascar. In a shift from the "Sea as a life" to a life on land or, one might say, the land as a life, Mission and his men founded, in a somewhat paradoxical move, the anti-colonial colony of "Libertatia," or "Libertalia" as it is spelled in some cases (47). From now on referred to as the "Libertatians" (96), they installed their settlement on the northern coast of the island, with no intention of invading and conquering the rest of the territory, which had long been populated by a tribe of natives living further inland and the many unique animal species of Madagascar, among them the lemurs who predominantly occupied the forests. The lemurs were sacred beings in the eyes of the natives, a specific aspect that became crucially important one day when Martin, a member of Libertatia, killed a lemur, who, as he claimed, had stolen his mango. Not only did Martin single-handedly violate the liberty lovers' law of common property by assuming that the fruit belonged exclusively to him, but more damningly, his killing of the sacred animal equalled war with the natives, which is why Mission, in his function as the captain and leader of Libertatia, immediately took action in expelling Martin from the community. That could not undo the harm that was caused, though, but quite on the contrary, the chain of events only accelerated, when Martin, now an outcast, made his way to the natives to inform them about the incident, without, however, disclosing that it was he who had killed the lemur, thus directing the natives' anger at the other Libertatians. Mission, in a prophetic moment right after the expulsion of Martin, had foreseen that Martin would do exactly that, but suddenly having been overcome by a "paralyzing fatigue" (Burroughs 1987, 52), he immediately fell asleep, which rendered him unable to prevent Martin from spreading his lies among the native community. Soon, then, the Libertatians had to face the natives in a bloody battle; many people died and the fate of the colony was sealed.

An extra level, however, is added to the story when it turns out that Martin actually did not act on his own, but was fulfilling the orders of the so called "custodians of the future" (Burroughs 1987, 52), a secretive board hovering above events in order to guarantee that the status quo on the entire planet remained balanced, or that, more precisely, the "prerecorded and therefore totally predictable universe" (Ibid.) went its course without the slightest of frictions. The true name of this control regime was the "OGU," the "One God Universe" (CCRU 2017, 37), implying that the custodians of the future were themselves only the delegates of a higher, transcendent power, namely God and his son Jesus Christ, who both represented the only substance and voice of everything that there was. Ultimately, it was in their name that the custodians sent Martin to 
distract and destroy life in Libertatia, an intervention that had become necessary as the reality of the existence of a resolutely autonomous community defied the monocausal order of the OGU. Mission and his fellows' experiment in self-sustained living might inspire others, the new form of living potentially being as contagious as a virus and altering the prearranged order of events, the custodians feared: "If three hundred man-then three thousand, thirty thousand. It could spread everywhere. It must be stopped now" (Burroughs 1987, 52, emphasis in original).

As tragic as the custodians' instructions to Martin turned out to be for the destiny of Libertatia, Mission himself, even before the colony was destroyed, had already directed his interests toward the creation of yet another community, namely an intimate and decisively peaceful bond with the lemurs. Spending more and more time in the forests, he tried to make direct contact with the primates, and thanks to an experienced native supplying him with a potent drug called Indris-its name signifying "look there" in native language (Ibid., emphasis in original)—he eventually managed to see the fleeting creatures, who otherwise remained invisible as they only needed to accept a discernible shape when they had to take a breath every once in a while. Finding a close companion in particularly one of them, Mission "often slept with the lemur beside him on his pallet, and had named the lemur Ghost" (Ibid.), which was the term that the natives had chosen to refer to the lemurs in general. Apart from the fact that they were mostly invisible, what justified this naming was not least that they participated in the realm of the "MU", the "Magical Universe" of polyculture (CCRU 2017, 40), in which not only the monocausal order of the OGU, but also the hierarchy of the species, the chronology of time, and the human limits of language were left behind. Instead, life in the MU was characterised by a purely immanent process of forces of becoming, which had present, past, and future as well as all other categories of being continuously expand in contingent ways. While Mission discovered this cosmos, the battles between Libertatians and natives however increased, and eventually he had to realise that, for his own survival, he had to flee the island and sail back out into the sea, an escape that abruptly ended in the middle of a great storm, which buried him beneath the waves. Yet, whether this last known event marked the ultimate end of the Libertatian dream or perhaps just a transition toward another chapter of the story that remains to be told, is an option that depends entirely on the speculation sparked by the CCRU as to whether the waves of the sea might just as well be conceived as only a further expression of the tumultuous, immanent forces of life, Mission getting lost in the sea thus possibly representing an even more intimate bond with the MU (CCRU 2017, 52).

In any case, the return of the powers of the sea can be said to represent both an opening as well as a return to the very beginnings of the stories of Libertatia, which is to say that the sea equally serves as a frame for the many additional sets of relations and events that unfolded in the long inbetween sequence on land. Individually recounted, they can be named in the form of an anticolonial colony, the orchestration of murder and war, a post-human community, and, more generally, a conflict between transcendent, monopolistic power and immanent, plural forces. In conjunction with the initial set of relations and events from aboard the ship, the resulting overall narrative spans an extremely vast array of political and social, religious and metaphysical, ecological and species-related matters, whose interrelations present a singular framework for the discussion of self-organisation that is at work within them. Most obviously, perhaps, it is the 
anarchist tradition of self-organising principles that surfaces on several accounts, which is why I will focus on anarchist self-organisation first, before I will then seek to unravel the implications of the sometimes subtler references to cybernetic and vitalist-materialist self-organisation.

\section{Anarchist Self-(Dis-)Organisation. The Desire to Rebel}

Not long into the stories of Libertatia, anarchist self-organisation shines through in perhaps its clearest form. In the event on sea, when the Victoire's battle with the English enemies led to the killing of all captains and lieutenants on board, the remaining men found themselves confronted with the sudden absence of not only their former leaders, but also the sovereign order that they represented and put in place. The resulting disorder brought about the chance for a re-organisation of social relations, an opportunity that the sailors immediately seized when they decided not to imitate any previous maxims, but to create a new form of organisation, which entailed that everyone had direct and equal voting rights while the appointed captain only had the right to execute the voting result. This distinct course of action aboard the Victoire represents in many ways an anticipation of the very nucleus of anarchist self-organisation, a parallel that becomes apparent by taking a look at the first systematic introduction of self-organising principles by Mikail Bakunin in the early anarchist days from the mid-19 ${ }^{\text {th }}$ century.

Bakunin's social libertarianism was grounded, first and foremost, on the utmost contempt for the modern state, a political institution, which, in his view, equalled the repression of the masses through a mechanism of top-down-governance characteristic for feudal, bourgeois, and Marxist state interpretations alike, which is to say that the order of representative parliamentarianism or any other popular representation was just as misguided as the order of the king. In either case, the state instituted a body of legislation that took decisions for the masses instead of letting them make decisions for themselves, even if, in its democratic variation, the people were given at least the right to elect those who were to make decisions for them. In a word, the rule of the state was necessarily defined by the rule of a few over the many, and it was this hierarchical and, more importantly, exclusionary relation that the "free organization" ([1873] 2005, 24) or "self-government of the commune" (206), as Bakunin called self-organisation at the time, was supposed to turn on its head: "no state," Bakunin proclaimed, "howsoever democratic its forms, [...] is capable of giving the people what they need: the free organization of their own interests from below upward, without any interference, tutelage, or coercion from above. This is because no state, not even the most republican and democratic, not even the pseudo-popular state contemplated by Marx, in essence represents anything but government of the masses from above downward, by an educated and thereby privileged minority which supposedly understands the real interests of the people better than the people themselves" (Ibid., 24). Hierarchy, to be precise, was not completely rejected in free organisation, but in crucial difference to the state, it was to manifest itself only in the form of an executive hierarchy, in which selected delegates in federations were directly bound to the choices of the many from within the communes.

Regarding its underpinning socio-political mindset, anarchist self-organisation can be said to be an expression of what Bakunin called the "desire to rebel" ([1882] 1970, 9, emphasis in original), an 
inherent human tendency never to accept any form of subordination, which in 1910 still resonated in Emma Goldman's phrasing of the anarchist "spirit of revolt" ([1910] 1969, 63). On a side note, it should be noted that Bakunin's characterisation of the desire to rebel as a natural instinct might be regarded as a form of essentialism (for such criticism cf. Newman 2016 and further references of post-anarchism), but a close reading of how he derived the concept from the myth of the Fall of Man, or more precisely from the insinuation of the snake (cf. [1882] 1970, 1-2), might stimulate the interpretation that the desire is to be seen as rather prompted, or "soufflé," as Derrida would have it with Artaud (cf. Derrida [1978] 2001), and thus as much more of a construct than an essence. Regardless of such finesse, one of the most trenchant formulations of the anarchist desire or spirit is definitely owed to John Henry Mackay, him having once written a short aphorism, which figured as the epigraph of one of Goldman's essays and which ends with the following words: "I am an Anarchist! Wherefore I will Not Rule, and also ruled I will not be!" (cf. Goldman [1910] 1969, 47). Whereas Mackay, in this exclamation, spoke in the singular form, the deeper social libertarian implications are, of course, that neither should anyone rule over the commune nor should the commune rule over anyone else, or differently put, neither should anyone rule over us, nor should we rule over anyone else. On that account, the "self" in self-organisation can be said to refer, first and foremost, to this very "we," a self-determining we claiming that it is only they who should organise their ways of life, not any other superior power reigning from outside or above.

The fact that the formation of such we presupposes not least an affective dimension has been highlighted perhaps most strongly in recent anarchist and anarchism-infused debates, the Invisible Committee, for example, having declared not without a touch of pathos that "[t]o organize is not to give a structure to weakness. It is above all to form bonds-bonds that are by no means neutral-terrible bonds. The degree of organization is measured by the intensity of sharingmaterial and spiritual" (2009, 15, emphasis in original). There is no we, in other words, without social connections and ties based on a shared experience of intensity binding everyone involved together.

The realisation of a rule from below, the desire to rebel, and the forming of affective connections all being more or less explicitly present in the "Republic on the Sea," it seems that the tale of Libertatia provides an almost paradigmatic example of anarchist self-organisation, but a number of inconsistencies suggest that Libertatia is, at the very same time, its subversion, and this is where things start to get really interesting. For one thing, in Johnson's early draft of Libertatia, Caraccioli, who, despite having fled the clergy, was still a firm believer, had the crew solemnly declare that they fight "A Deo a Libertate, for God and liberty" (1728, 16, emphasis in original). This implied that the "Republic of the Sea" was taken under the guidance of the Lord, but in anarchism, the figure of God most certainly does not promise liberty, as Caraccioli wanted to believe; instead, it is presented as just another transcendent power that is designed to infuse subordination. Bakunin insisted that the acceptance of the mere possibility of God contradicted human freedom, one of his most unapologetic theses, in this respect, reading that: "God being master, man is the slave" ([1882] $1970,24)$. Indeed, from his materialist standpoint, it was only logical to assume that the idea of God led to the degradation of everyone else, because if the omnipotent spirit was the primary source of all things, then all human beings, but also all other matter-bound beings necessarily had 
to be secondary, inferior, and therefore unfree (cf. Ibid.; for a reaffirmation of this deduction cf. Goldman [1910] 1969, 53). It is only through Burroughs' variation, then, that the stories of Libertatia implicitly realigned with this anarchist critique, namely when Burroughs decided to completely obliterate all positive references to God.

More importantly, though, it is the further development on land that has the stories of Libertatia perform an alteration of anarchist self-organisation. Crucial impulses come from the murder of the lemur and subsequent events, that is, from Martin killing the monkey after he had allegedly stolen his mango, and Mission being unable to stop Martin from then spreading his lies about the murder among the natives. In initially equal ways, both Martin and Mission's behaviours reveal how anarchist self-organisation, although intended to be a realisation of maximum social freedom, is nevertheless, in some sense, dependent on the limitation of the freedom of every member of the community or the community as a whole, and the specific way that this becomes apparent has to do with the fact that Martin and Mission both essentially display acts of failure: very concretely, in Martin violating the rule of common property and peaceful conduct, and in Mission violating his responsibility as a captain to not just condemn the murder, but also make sure that the danger of the murdering subject was contained, the two men failed to apply the rules of the colony to themselves, precisely this form of ex negativo affirmation indicating how much self-organisation is, despite all of its liberating intentions, still strongly based on governance or rule, only that the subject and object of rule are one and the same. Be it with regard to one or many, anarchist selforganisation is likely to amount to a process of internalisation of power much rather than its deferral or absence, and this quality of internalisation can be named, quite specifically, with a notion otherwise used to denote a very different, bourgeois form of power, namely the notion of self-discipline (cf. Foucault 1977). The historical irony of this insight, then, is that anarchist selfdiscipline is not entirely different from the discipline of their very enemies, the bourgeois class having represented, of course, one of their biggest counterparts in the time of the $19^{\text {th }}$ and $20^{\text {th }}$ century.

Now, while this interpretation of Libertatia's narrative suggests that its combined story undermines anarchist self-organisation in disclosing its intimate relation to power, the resulting argument of which would be that anarchist self-organisation equals order in a most rigid sense, the ultimate lesson that can be drawn from Libertatia is exactly the reverse; namely, anarchist self-organisation can indeed be extremely liberating, but only if it becomes porous vis-à-vis the more precise implications of its own failure, or of Mission's failure, for that matter, which, at a closer look, has to be differentiated from that of Martin. The difference between them is that, despite both representing behaviours of non-discipline, Martin's failure to discipline himself equaled him applying discipline or sheer brutal force against someone else, whereas Mission failed to exercise discipline or force no matter against whom. What Mission did was that, instead of forcing himself to act out against Martin, instead of perhaps violently preventing him from reaching the community of the natives, he gave in to a sudden fatigue, and thus, in simply accepting to fall asleep, he neither ruled against anyone else nor against himself. 
Although it might be counter-intuitive, precisely this moment of sleep can be said to be the most radical and indeed the only logical consequence of anarchist self-organisation. After all, if anarchist self-organisation is fuelled by the desire to rebel, that is, if self-organisation is supposed to be the implementation of the refusal to rule no matter who or be ruled no matter by whom, then the only consistent interpretation of self-organisation is indeed that it must include the refusal to rule or be ruled not only by others, but also by the self-making the failure to discipline oneself the paradoxical completion of self-organisation. Thus, in the same way that anarchist self-organisation implies the folding of power, in the same way that it implies the identity of the subject and object of power, it equally implies the folding of the refusal of power, or the identity of the subject and object of the refusal of power, and of course, in its most immediate social-libertarian sense, this conclusion does not only concern the subject and object as an individual, but also the subject and object as a community. In short, this is how anarchist self-organisation is always already self-disorganisation, a programme that is paradoxically both a programme for the liberation of the self through organisation and a programme for the liberation of the self from organisation.

Certainly, in the case of Mission, the individualist aspect of his complete refusal might suggest that at the centre of this paradoxical divide resides predominantly an unresolvable conflict between the many and the one, but again, the self in self-organisation and self-dis-organisation can refer to an individual just as well as it can refer to a community, and more importantly, it refers predominantly to the organisation within that self, not between different individual or collective selves. Finally, with respect to Mission, it is worth adding that his behaviour was guided not least by the impulse to go through the demise of Libertatia only to see the emergence of a wholly different community within the $\mathrm{MU}$-and this latter aspect brings me to discussion of the cybernetic concept of self-organisation, in which the MU will, in some ways, play a decisive role.

\section{Cybernetic Self-(Dis-)Organisation. Noise from Order}

Strictly speaking, cybernetic self-organisation fully enters the narrative of Libertatia only when the authors of the CCRU decide to engage in it, but already several relations and events constructed by previous voices can be said to be of great cybernetic significance. The first of them is the initial event on sea, which only just served as an example for the formation of anarchist self-organisation, but in order for this to become comprehensible it is important to mark at least three basic axioms characterising cybernetics in general.

First of all, as opposed to anarchism, or many other philosophies, for that matter, cybernetics understands agents not in terms of subjects and objects and their internal structures, but in terms of systems and environments and the processes unfolding within systems as well as those unfolding between systems and environments. Adapting arguments from behaviouralism and technical engineering, cybernetics holds that, no matter if one has to do with a machine, an organism, or a community, the defining category of agency is that of a system continuously reacting to the effects of its own behaviour both inside it and between itself and the outside, the recursive mechanisms thus installed as feedback loops being supposed to guarantee the system's stability over time (cf. for Wiener/Bigelow/Rosenblueth 1943). Secondly, the interactions within the system 
and between system and environment are conceptualised in terms of the interrelation of communication and control, which is to say that the better the information transfer within the feedback loops in the system or between system and environment, the less there is a chance of noise or information disorder undercutting control (cf. Wiener [1948] 2013). While this second aspect is clearly derived from communication and information theory, the third stems from the theory of thermodynamics, cybernetics namely having adopted specifically its second law according to which the entropy within an isolated system necessarily increases over time, entropy being the measure for the irreversibility of processes of temperature transfer from warm to cold, or, if very loosely translated into more applicable terms, the measure of the irreversible rise of noise or, again, disorder (cf. Wiener [1950] 1988).

With that being said, the conflict on sea can be reevaluated as the event of a system, the Victoire, having had to face an interaction with another system from its environment, the English vessel, which resulted in an entropic increase of noise within that first system. More precisely, with all captains and lieutenants killed, the previous order of information aboard the ship was no longer in place, the rules of communication installed by the captains as well as the feedback channels from crew to captains and back had been undone, and thus the crew found itself in a situation of uncontrolled relations, which potentially threatened its existence.

The cybernetic analysis of the subsequent formation of the "Republic of the Sea" on the very basis of such situation of noise demands for self-organisation to come into play specifically. Very briefly put, in the light of the theory of self-organisation presented by Heinz von Foerster in the 1960s, it can be stated that noise possesses its very own internal dynamic, and the surprising factor of this dynamic is that, without any external interference, it automatically tends to transform into relations of order, meaning that noise has the capacity to let order emerge from within itself, a principle that Heinz von Foerster gave the name of "order from noise" (Foerster [1959] 1981, 15; cf. also Mersch 2013). In this sense, it can be said that Mission and his crew's invention of the new order of liberty was a form of self-organisation in that it emanated directly and precisely from the high level of noise having been caused aboard the ship. Without noise, there would not have been a new order. Importantly, one of the main differences between this and the anarchist concept of self-organisation is that the "self" in cybernetic self-organisation refers less to a subject, be it collective or individual, and more to the mechanical quality of a process. To an extent, the "self" in cybernetic self-organisation stands in for "by itself," and in consequence, the entire anarchist paradox discussed under the notions of self-discipline and failure does not present itself in cybernetic terms-which is not to say, however, that no other paradoxes are involved.

A properly cybernetic paradox starts to come into view by looking at yet another event from Libertatia that has been discussed before, namely Martin's killing of the lemur and Mission's reaction to it, a case that, from a cybernetic perspective, evokes Ashby's experimentation with the homeostat from the late 1940s and 1950s (cf. Dany 2013, 52-56; Pickering 2005). The homeostat was a machine designed by Ashby in the interest of modelling the homeostatic mechanisms of the organism and particularly the human brain; a simple example of such organic mechanisms is the regulation of body temperature at a constant level via sweat. Very quickly described, the 
homeostat's technical architecture reproduced such mechanisms by transforming electric inputs into outputs while constantly maintaining a certain level of voltage inside it, thus making sure that a certain predefined order, a norm, or rather a certain interval corresponding to that norm was never exceeded. The latter aspect of a normative interval is also called meta-stability in cybernetics and can be traced back to its very early beginnings (cf. Vogl 2016), but Ashby's work on the homeostat not only aimed at meta-stability, it aimed at "ultra-stability," as Ashby termed it (cf. Ashby 1954), a state of equilibrium which was supposed to guarantee total control even if, for some reason, meta-stability was completely disturbed. The essential twist came from the introduction of a specific feedback mechanism into the machine: whenever the normative interval was transgressed through some random input drastically lowering or increasing the level of voltage, the homeostat automatically activated a relay which, by means of inverting the polarity of the electrical power or, for example, by modifying the resistance of the electrical circuit, immediately led to the restoration of order. And in case the first attempt at reestablishing inner balance was not a success, the relay mechanism simply got repeated until it finally was.

The more general consequences of this experiment can be said to imply an extension or intensification of Foerster's principle of "order from noise," even if Ashby's research historically preceded that of Foerster. In a nutshell, Ashby's homeostat not just confirms the theory that information disorder can evoke order, but more than that, it shows how disorder can evoke order exactly via injecting even more disorder. Because that is what the homeostat is essentially about: whenever the order defined by a norm respectively a normative interval is being undone, the relay mechanically fights the caused disorder by inserting yet another dosage of disorder, which works by essentially neutralising the original shock. The extended definition of self-organisation that can be derived from that argument is that not only can disorder automatically create order, but in case of a disturbance of order, further disorder can automatically restore it. In the stories of Libertatia, the event of the murder of the lemur exemplifies just that, but only if regarded with respect to the OGU, which, in cybernetic terms, too can be perceived as a self-organising system: from the standpoint of the custodians of the future, the existence of the new system of Libertatia represents a momentum of disorder in the system of the OGU, and the way to control this deviation is to insert more disorder into the universe by having Martin kill the lemur, the calculation that this distraction and its further effects will eventually bring Libertatia down and inversely restore order within the OGU eventually playing out just like they thought.

Having come this far, it again seems that the stories of Libertatia, also in the case of cybernetic selforganisation, fulfil primarily the function of exemplification, and furthermore, it seems that they exemplify only how extremely flexible and rigid cybernetic self-organisation can be at the same time, even the paradox of fighting disorder with disorder leading only to more stability. Yet, just like with anarchist self-organisation, an essential detail from the narrative turns everything around, revealing suddenly how cybernetic self-organisation too is an inherently self-dis-organising process. The specific aspect in question is that, although the custodians of the future successfully managed to wipe out Libertatia and thus seemingly let the OGU re-organise itself, what they did not manage to undo was Mission's excursions into the forests which made him engage in a new community with the lemurs. More to the point, it was only and precisely after Martin had killed the 
lemur that Mission started to fully commit to a life in the forests, which invites the interpretation of there being a correlation between the two acts, a correlation in the sense that the intervention of the custodians, like a feedback mechanism gone wrong, unwillingly turned out to be the very impulse for or cause of Mission's relation with the lemurs and, in consequence, also his stepping into the MU. Within the MU, in turn, both time and personal identity completely spiralled out of control, with circular recursions of time resulting in time rifts, which even made it possible to think of Mission and Burroughs as the two faces of one and the same person.

All of this was caused or at least intensified by the intervention of the custodians of the future, a peculiar inconsistency which, against the backdrop of Foerster's and Ashby's concepts of cybernetic self-organisation, leads to the assumption that fighting disorder with disorder, although intermediately leading to a restoration of order-after all, Libertatia was indeed destroyedeventually invokes only further disorder-the flourishing of the MU. In other words, there is no creation of order without the simultaneous creation of more disorder, even if that order comes from fighting disorder with disorder. And interestingly enough, in some way, Foester's theory of self-organisation anticipated just that, namely when, in strictly applying the second law of thermodynamics to processes in isolated systems, Foerster stated that: "if one assumes that [the adiabatic] envelope contains the self-organising system proper, this system turns out to be not only just a disorganizing system, but even a self-disorganizing system" ([1959] 1981, 4). In the case of the all-encompassing OGU as an isolated system, the blooming of the MU paradoxically situated within it equals exactly such entropic self-dis-organisation. Other social systems, which are generally non-isolated, might not be self-dis-organising in this strict sense, but they are still disorganising insofar as their generation of order creates disorder in their environment and thus a further potential for change. In sum, cybernetic self-organisation is the principle order from noise, but at the same time it is the principle of noise from order.

\section{The Curiosity for Panic. Vitalist-Materialist Conclusions}

Readdressing the original question of self-organisation and liberation, the stories of Libertatia so far have elucidated how both the anarchist and the cybernetic concept of self-organisation implicitly project its potentially liberating opposite of self-dis-organisation. In the case of Libertatia as a self-organised anarchist commune, Mission having given in to the impulse of sleep precisely when he was supposed to discipline himself in order to fulfil his obligations for the community indicated how anarchist self-organisation as a refusal to be ruled or rule implies self-disorganisation in the sense of refusing particularly internalised rule; in the case of the OGU as a selforganising cybernetic system, Mission having been provoked to fully enter the world of the lemurs and the MU and thus increase the level of disorder within the OGU precisely by the custodians' attempts to reinstall order within the OGU indicated how cybernetic self-organisation implies selfdis-organisation in the sense that more order necessarily provokes more disorder.

To conclude, I intend to add, just very briefly, a final reading of the tale of Libertatia as containing, in addition to anarchist and cybernetic self-organisation, a third option of vitalist-materialist selforganisation, one of its decisive advantages over the other two being that it not just implies, but 
indeed rather embraces processes of self-dis-organisation, thus accentuating the liberating aspect of self-dis-organisation in perhaps its most obvious form. Not surprisingly, vitalist-materialist selforganisation is present not so much in the commune of Libertatia or the system of the OGU, but in the forests, among the lemurs, and more precisely in the MU. Burroughs indicated the MU's vitalist-materialist implications most clearly when, in describing how Mission went looking for the lemurs for the very first time, he wrote that "Captain Mission did not fear panic, the sudden, intolerable knowing that everything is alive" $(1987,50)$. This peculiar characterisation of panic was elsewhere expanded on when Burroughs alluded to its etymological roots of "panikós" and the Greek God Pan, the god of nature, the forests, and wildlife, who, in Burroughs' own reasoning, further represented a world of multiple healing powers opposed to the Christian monopolisation of powers in the figure of Jesus Christ (cf. Burroughs 1991, 23-28). Thus, in stating that Mission did not fear panic, Burroughs portrayed his protagonist as someone who is open to or indeed actively seeking contact with the plural and wild powers of Pan, with the forces of life that reside everywhere, with the forces that, once he got in touch with them, might fundamentally change him. That is exactly what happened when Mission got to know the lemurs and decided to live with one of them, the relationship to his fellow Ghost equalling a form of self-organised inter-species living through which Mission's life is transformed particularly by getting directed toward the radical processes of unorganised becoming in the MU. Borrowing from Johnson's original characterisation of Mission as a man defined not least by his "Curiosity" (1728, 2), Mission's lack of fear and his actions can ultimately be translated in terms of a curiosity for panic that proposes an ongoing becoming-other through the welcoming of the self-dis-organising powers of the self-organisation of forces. In the MU, self-organisation is no longer a matter of subjects or systems, but a matter of forces and their continuous merging and falling apart.

This, at least, is what a vitalist-materialist interpretation on the basis of Félix Guattari and Donna Haraway might conclude, the latter, of course, not strictly being a vitalist materialist, but still definitely a materialist. Mission's relationship with the lemur might serve as a prime case for Haraway's reformulation of self-organisation, or auto-poiesis, in terms of sym-poiesis, a neologism, which she introduced in order to emphasise the primary relationality as well as the "making-with" and "becoming-with" in self-organisation, which included the possibility of unexpected change (cf. 2016, 58-98). Interestingly, Haraway mentions a wildlife preservation project designed to aid the survival of lemurs in Madagascar as one example of human-animal sympoiesis (Ibid., 81-85). More fundamentally, though, it is Félix Guattari's concept of auto-poiesis as chaosmosis that highlights the core consequences of a vitalist-materialist interpretation of self-organisation (cf. 1995, cf. also Braidotti 2013). In a critical reading of Francisco Varela's auto-poiesis according to which the concept defines the machine's capacity to produce and reproduce its own organisation as well as its regulating limits and thresholds, Guattari derives the immanence of auto-poiesis, which has it that every process of formation is always already pregnant with the forces of disorder or chaos ready to dissolve it: "Formations of sense and states of things are thus chaotised in the very movement of the bringing into existence of their complexity. At the source of a world's constitution there is always a certain modality of chaotic discomfort in its organicity, functionality and relations of alterity" $(1995,80-81)$. This chaosmosis of auto-poiesis lets self-dis-organisation appear as a co- 
originary force independently of which self-organisation never exists, a quality of the chaotic relations of forces that inscribes change in every order and that one cannot but affirm.

Mission's curiosity for panic is exactly this affirmation, it is a life within the immanence of self-(dis-)organisation. Not just in the $\mathrm{MU}$, but in the entire narrative of Libertatia, his character is itself nothing but a self-(dis-)organising force: he was involved in every self-formation of order only to open up escape routes that led to further self-dis-organisation, from the "Republic of the Sea" to Libertatia to the life in the forest to, ultimately, the Sea, which meant his death or perhaps yet another life. He was the actualisation of a voice which, as Burroughs noted, repeated "'[o]ut, and under, and out, and out"' $(1987,54)$ in his head, a voice, a ghost, perhaps, or a vector, a movement constantly driving for change. Similarly, the stories of Libertatia, in a more abstract sense of a dramaturgy of reiterations, are also but a continuous process of self-organisation and self-disorganisation, with every new author altering it from within, with every new draft adding to the previous one and so further liberating its forces. From the liberated ship that, in Johnson, was still guided by the Lord, to the abandonment of God's influence via Burroughs, to the settling of the liberty lovers on land and the subsequent destruction of the colony of Libertatia which only reinforced the creation of the connection to the lemurs, to the introduction of the MU and chaotic time rifts in the CCRU, the narrative of Libertatia transformed with every new turn. The writings of the stories of Libertatia themselves performed the curiosity for panic as a constant affirmation of self-(dis-)organisation, and far from of having come to an ultimate end, the process is only waiting to be continued in the future.

I would like to thank Agnes Quackels, Silvia Bottiroli, and Daniel Blanga Gubbay for having given me the opportunity to present a very early draft of this paper in the framework of the conference The Return of the Fantastic Institution which took place at BUDA, Kortrijk, Belgium, in February 2018.

\section{Works Cited}

Argyropoulou, Gigi. 2018. "Theatre in Crisis and the Political turn: Thoughts on Instituting Otherwise." Unpublished paper presented at the conference Systemic Crisis in European Theatre, Goethe-Institut London, 27 April 2018.

_-_ 2017. "Collective Horizons. Rethinking the Performative and the Political. (Im)Possibilities of Being Together." In Performing Antagonism. Theatre Performance, and Radical Democracy. Edited by Tony Fisher and Eve Katsouraki, 171-185. Basingstoke: Palgrave Macmillan.

Ashby, William Ross. 1954. Design for a Brain. New York: John Wiley \& Sons. https://doi.org/1 0.5962/bhl.title.6969

Bakunin, Mikhail. (1873) 2005. Statism and Anarchy. Edited and translated by Marshall Shatz. $4^{\text {th }}$ edition. Cambridge: Cambridge University Press.

-. (1882) 1970. God and the State. No translator listed. New York: Dover Publications. 
Berardi, Franco "Bifo". 2017. Futurability. London and New York: Verso.

Bey, Hakim. 1991. TAZ: The Temporary Autonomous Zone. Brooklyn: Autonomedia.

Bidston Observatory. 2018. "Annual General Exchange 2018." Accessed 19 December 2018. http://www.bidstonobservatory.org/age_1.

Braidotti, Rosi. 2013. The Posthuman. Cambridge: Polity Press.

Burroughs, William S. 1991. Ghost of Chance. New York: Grenfell Press/Library Fellows of the Whitney Museum of American Art.

1987. "The Ghost Lemurs of Madagascar." Omni Science Fiction 103: 48-54, and 118.

1981. Cities of the Red Night. New York: Holt, Rinehart and Winston.

Chomsky, Noam. 1970. Introduction to Anarchism, by David Guérin, vii-xx. New York: Monthly Review Press.

Cohn, Jesse. 2002. "What is Postanarchism 'Post'?" Postmodern Culture 13 (1).

http://pmc.iath.virginia.edu/issue.902/13.1cohn.html

Cohn, Jesse, and Shawn Wilbur. 2003. "What's Wrong With Postanarchism?" The Anarchist Library. Accessed 17 February 2018. https://theanarchistlibrary.org/library/jesse-cohn-and-shawn-wilbur-what-s-wrong-withpostanarchism.

Cybernetic Culture Research Unit. 2017. "Lemurian Time War." CCRU. Writings 1997-2003, 33-52. Falmouth: Urbanomic.

Dany, Hans-Christian. 2013. Morgen werde ich Idiot. Hamburg: Nautilus.

Derrida, Jacques. (1978) 2001. "La Parole Soufflée." In Writing and Difference, 213-245. London and New York: Routledge.

Duda, John. 2013. "Cybernetics, Anarchism and Self-Organisation." Anarchist Studies 21 (1): 52-72.

Evren, Süreyyya, and Duane Rousselle, eds. 2011. Post-Anarchism. A Reader. London: Pluto Press.

Foerster, Heinz von. (1959) 1981. "On Self-Organizing Systems and Their Environments." In Observing Systems, 222. Seaside, CA: Intersystem Publications.

Foucault, Michel. 1977. Discipline and Punish. The Birth of the Prison. Translated by Alan Sheridan. New York: Pantheon Books.

Goldman, Emma. (1910) 1969. "Anarchism. What it really stands for." In Anarchism and Other Essays, 47-67. New York: Dover Publications.

Graeber, David. 2002. "The New Anarchists." New Left Review 13: 61-73.

Guattari, Félix. 1995. Chaosmosis. Translated by Paul Bains and Julian Pefanis. Bloomington: Indiana University Press.

Haraway, Donna J. 2016. Staying with the trouble. Durham, NC: Duke University Press. https://doi.org/10.1215/9780822373780

Invisible Committee. 2015. To our Friends. Translated by Robert Hurley. Los Angeles: Semiotext(e).

__- 2009. The Coming Insurrection. No translator listed. Los Angeles: Semiotext(e).

Johnson, Charles. 1728. The History of the Pyrates. Volume II. London: T. Woodward.

Little, Benerson. 2016. The Golden Age of Piracy. La Vergne: Skyhorse Publishing.

Lorey, Isabell. 2015. State of Insecurity. London and New York: Verso.

McEwan, John. 1963. "Anarchism and the Cybernetics of Self-Organizing Systems." Anarchy 31: 270-83.

Mersch, Dieter. 2013. Ordo ad chao - Order from Noise. Berlin/Zurich: Diaphanes.

Moten, Fred, and Stefano Harney. 2013. The Undercommons. Wicenhoe: Minor Compositions. 
Newman, Saul. 2016. Postanarchism. Cambridge: Polity Press.

Nobody's Business. n.d. "Mission Statement." Accessed 19 December 2018.

https://nobodysbusiness.wordpress.com/project-description/.

Pickering, Andrew. 2005. "A Gallery of Monsters. Cybernetics and Self-Organization, 1940-1970." In Mechanical Bodies, Computational Minds. Edited by Stefano Franchi and Güven Güzeldere, 229-245. Cambridge, MA: The MIT Press.

Ritsema, Jan. 2017. "On the PerformingArtsForum (PAF), an alternative artists, scientists and media-activists residency." Lecture presentation in the frame of the conference The Fantastic Insitution ad BUDA, Kortrijk, Belgium, 17 February. Accessed 20 February 2018. https://vimeo.com/206172780.

Ritsema, Jan, and Valentina Desideri. 2016. "PAF. Movement Research Definitive." In Turn, Turtle! Reenacting the Institute, edited by Elke van Campenhout and Lilia Mestre, 184-191. Berlin: Alexander Verlag.

Schaupp, Simon. 2017. "Vergessene Horizonte. Der kybernetische Kapitalismus und seine Alternativen." In Kybernetik, Kapitalismus, Revolutionen. Edited by idem et al., 51-73. Münster: Unrast.

Seitz, Don Carlos. (1925) 2012]. Under the Black Flag. New York: Dover Publications.

Stirner, Max. (1844) 1995. The Ego and Its Own. Edited by David Leopold. N. transl. Cambridge, UK: Cambridge UP.

Tiqqun. 2001. "L'hypothèse cybernétique." Tiqqun 2, 40-83. Paris: n.publ.

Vogl, Joseph. 2004. "Regierung und Regelkreis. Historisches Vorspiel." In Cybernetics. The Macy-Conferences $1946-$ 1953. Volume 2. Edited by Claus Pias, 67-79. Berlin/Zurich: Diaphanes.

Wiener, Norbert. (1948) 2013. Cybernetics or Control and Communication in the Animal and the Machine. Reprint of $2^{\text {nd }}$ ed. Cambridge, MA: The MIT Press.

Wiener, Norbert. (1950) 1988. The Human Use of Human Beings: Cybernetics and Society. New York: Da Capo Press.

Wiener, Norbert, Arturo Rosenblueth, and Julian Bigelow. 1943. "Behavior, Purpose and Telelogy." Philosophy of Science $10(1): 18-24$.

\title{
Biography
}

Georg Doecker, M.A., born 1988 in Vienna, Austria, is a PhD student at Roehampton University, London, and the recipient of PhD stipends from both Roehampton University and the TECHNE consortium. From 2015 until 2018 , he was a researcher for the DFG-funded project "Theatre as Dispositif" at Giessen University, Germany. His research interests include: Experimental theatre, dance, and performance of the $20^{\text {th }}$ and $21^{\text {st }}$ century; power relations and technologies of power; mimesis and theatricality; the work of Antonin Artaud. Latest publication: "Etc etc. Eine Meditation über Artauds letzte Worte." In "Landschaft mit entfernten Verwandten." Festschrift für Heiner Goebbels. Edited by Lorenz Aggermann et al., 259-270. Berlin: Neofelis, 2018.

\author{
(c) 2019 Georg Doecker
}

Except where otherwise noted, this work is licensed under a Creative Commons AttributionNonCommercial-ShareAlike 4.0 International License. 